\title{
Analysis of the Efficiency of China's Distance Economic Education in Force Majeure Circumstances
}

\author{
Kseniia V. Tsytsiura \\ State Institution of Higher Education "University of Educational Management" \\ of the National Academy of Educational Sciences of Ukraine, Kyiv, Ukraine \\ Jiaxing University, Jiaxing, China \\ http://orcid.org/0000-0002-4606-9287 \\ Ganna M. Romanova \\ State Institution of Higher Education "University of Educational Management" \\ of the National Academy of Educational Sciences of Ukraine, Kyiv, Ukraine \\ http:/ / orcid.org/0000-0002-2388-6997
}

\begin{abstract}
This article focuses on the latest approaches to the effective delivery of distance education for the students of economic specialties in China's higher education institutions in force majeure circumstances. Distance education was introduced due to the complex global epidemiological situation, unpredictable for the entire world community. The growing role and importance of distance learning in contemporary higher education overall and the education of economists in particular have been outlined. The need to use and constantly upgrade software and distance learning platforms is emphasized. The current Chinese approaches to the provision of the economists' distance education in higher education institutions are outlined. The efficiency factors of the economists' distance education in China's higher education institutions were determined and substantiated. Namely, the following efficiency factors were considered: importance of approbation and implementation of the new interaction methods among the participants of the teaching and learning process, game approach application aimed at the formation of motivation of students to study, the creation and continuous modernization of the informational and educational environment of the university, the provision of a free access to up-to-date digital technology and information and communication learning technologies, the use and efficient combination of distance learning platforms in teaching disciplines, the formation of digital competence of students and teachers, as well as the openness of the colleges and university management and faculty to change. The effectiveness study of distance education provision for the students of economics was experimentally tested. The results of distance learning and teaching during the semester in force majeure circumstances were
\end{abstract}


analyzed on the basis of empirical data from the students' survey at the Department of Economics of a state-owned Chinese higher education institution. The research findings emphasize the feasibility of studying and analyzing China's positive experience in the provision of distance learning economic education in force majeure circumstances. Recommendations for the implementation of China's experience in economists' training in Eastern European universities were elaborated and presented.

Keywords: distance education; economic education; force majeure circumstances; distance learning platform; digitalization of education

\section{Introduction}

Due to the quarantine caused by the COVID-19 pandemic, the problem of distance learning has become more acute at all levels of education. Modern university teachers, usually with sufficient autonomy in the choice of methods and forms of teaching, are faced with a set of technical, methodological and psychological problems, which took little time to solve. On the one hand, distance learning and its elements are widely used in higher education, however the urgent need for mass transition to distance learning forced quick organization of new interaction methods with students, updating the content of learning, applying different methods and forms of activity, developing and ensuring quality control. In our opinion, at this stage of development of higher education, including economic education, it is expedient to unite the efforts of scientific and pedagogical workers of different countries in ensuring education quality in a distance format, which determines the analysis of best educational practices around the world.

The rapid development of information technology is a prerequisite of the modernization of education worldwide. Distance learning has already become widespread, and it is gaining popularity rapidly every year. For example, in the United States, Canada, and the United Kingdom, virtual universities have been established as an alternative to traditional learning, where each student can be educated in basic distance learning courses at any university. Nowadays the European education policy takes into account "The Digital Agenda for Europe" initiative (European Commission, 2010a) and the European Economic Development Strategy "Europe 2020: A strategy for smart, sustainable and inclusive growth" (European Commission, 2010b), which emphasize the importance of using the benefits of information and communication technologies in the education sector and beyond the national borders.

The introduction of the new educational technologies into the organizational channel in Europe is expressed in the form of such novel social institutions as TV universities, tutoring and information centers, distance learning centers and retraining centers, which allows anyone to receive a proper education and obtain the desired major even in a systemic crisis and severe financial constraints of resources. However, despite the large number of scholarly works, the contemporary distance education in Eastern European countries occasionally 
continues to apply the outdated approaches, does not sufficiently use the opportunities of the fundamentally new teaching forms and methods. Compared with the countries of Western Europe and North America, where as early as in the late 1960s - early 1970s the introduction of open and distance learning began, in Eastern Europe a variety of correspondence training had been used for a long time. These included, in particular, extramural programs, such as in the former Soviet Union countries since the 1920s or "non-attendance" in Romania since the 1980s and other varieties in the countries of the former socialist camp.

In the post-totalitarian countries of Eastern Europe, there is a great number of contradictions in the distance learning system of specialists' training: between the need for a student-centered approach and an insufficient implementation of the students' individual educational trajectories; between the requirements for the formation of graduates' competencies and the imperfection of the information and educational environment of universities; between the development of distance learning technologies and the unwillingness of teachers to use them. Currently, an urgent problem of training the university-educated specialists in Eastern Europe is the use of modern advances in science and technology, the implementation of ideas aimed at integrating education and production, fostering the search for innovative pedagogical technologies. The introduction of groundbreaking foreign initiatives into the university programs of these countries contributes to the modernization of higher education and ensuring its quality assurance.

Currently, in Eastern Europe the organization of the educational process in the distance form remains local and unequally accessible. Moreover, it requires a continuous modernization and active digitalization training of the teachers. A significant role in the effective organization of this education form is played by the search and testing of the feasible interaction forms, in particular "teacherstudent" and "student-student". The factor of no less importance is the competent selection of the functional software - the computer and mobile platforms that will provide for high-quality learning under the conditions of distance education (Khan \& Ally, 2015).

To handle such complex tasks at the stage of reforming distance education in Eastern Europe, it is expedient to analyze, study and apply the trend-setting experience of other countries in the field of effective provision of distance learning, in particular the Chinese best practices. Due to China's policies of reform and openness, this country has created a real economic miracle over the past 40 years, having transformed from a poor country with outdated infrastructure into a flagship of the world economy. In recent decades, Chinese universities have joined in the world's top rankings, and research has become an important part of the production processes. Thus, it is not surprising that the state pays great attention to economic education, the main purpose of which is training professionals in the field of international economics and business to ensure further GDP growth, to maintain living standards and economic growth. However, the global epidemiological situation in the world, which arose in early 
2020, makes it especially important to find new forms, tools and methods of teaching the university students in general and the future economists in particular, which could be used during the academic year without compromising the effectiveness of teaching and learning material. That said, the development and reform of distance economic education is becoming especially important globally.

In China, distance learning provision has been successfully integrated with the traditional education for many years, but now, when the epidemiological situation in the world leaves no chance to make use only of the traditional learning principles, gaining insight about the effectiveness of online platforms as well as of the teaching methods in force majeure circumstances, and testing the new forms of educational interaction between teachers and students came to the fore of the country's national policy aimed at the development and reform of distance education. However, at the very beginning of the distance learning introduction in force majeure circumstances, the teachers of Chinese universities held that creating an atmosphere of fruitful online learning is no easy task at all, and there was no guarantee for the effectiveness of such learning. Some methods of interaction between students and teachers are not sufficiently deployed in the distance form. For instance, during the learning process the network or platform used for classes can be overloaded and thus experience delayed actions, which will tell on the learning outcome. That is why work has begun to enhance the educational content and quality of distance learning, which should be guaranteed by China's higher education institutions.

\subsection{Empirical background}

According to the purpose of the study, the following tasks were set for the experiment: to develop a questionnaire for the students (see Appendix A), to conduct a survey among the target audience, to identify the factors that determine the efficiency of distance economic education in China. A study of teachers' work and students' education in Chinese higher education institutions during a special epidemiological situation was conducted from February 2020 to June 2020. An anonymous questionnaire survey was conducted with the students of the Department of Business Economics, Jiaxing University, the city of Jiaxing, China. 498 students (including freshmen, sophomores, third year and undergraduate students) majoring in Business Economics from the Department of Economics of Jiaxing University (n. d.) took part in the survey.

The survey of students was aimed at determining the needs of future business economists in distance learning, identifying its problems and development trends. During the survey, the students were asked 15 questions regarding the overall evaluation of distance learning level in their educational institution, determination of the feasibility of using different educational platforms, as well as the forms of interaction with teachers and classmates in the learning process, assessment of the teachers' and their own digital literacy, personal opinion as for the identification of the most effective forms and methods of learning the material during the distance learning process. 


\subsection{Research hypothesis}

Analysis of China's distance education effectiveness in force majeure circumstances can form the rationale for the transfer of innovative elements of distance learning to the context of Eastern European economic education. In particular, the results of evaluation of the efficiency and effectiveness of distance learning in force majeure circumstances by Business Economics students will help to develop effective recommendations for the implementation of positive experience in methods of interaction among teachers and students, improving educational content, providing effective online learning control, development of digital competencies of teachers and students.

The purpose of the study is to identify and experimentally substantiate the effectiveness criteria of China's distance education in business and to elaborate the recommendations for the implementation of good practices in the Eastern European university training of economists.

\section{Methodology}

To achieve the purpose of the study, address the tasks set and test the research hypothesis, a toolbox of methods was used, in particular:

- theoretical ones: the method of analysis, which allowed examining the concepts and approaches outlined in the scientific sources; the method of synthesis, which was applied to shape the framework of the research; the method of comparison, which was used to identify the peculiarities of students' attitudes to various aspects of distance learning; the method of systematization, which was applied to determine the factors of effectiveness of distance education; the method of generalization, which allowed formulating recommendations and conclusions.

- empirical ones: diagnostic methods (questionnaires) were applied to study the effectiveness of distance economic education in terms of force majeure circumstances on such indicators as the use of online platforms, content analysis of online classes, effectiveness and efficiency of online learning; praximetric methods (analysis of activity products) were used to monitor the training quality; statistical methods (processing of experimental data) were applied to analyze the results of empirical research.

To identify problem areas of distance economic education, namely Business Economics major, at Jiaxing University, Jiaxing, China, an anonymous survey was conducted with participation of 498 students of the $1^{\text {st }} 4^{\text {th }}$ year of study majoring in Business Economics from the Economics Department. The quantitative research conducted at the university involved the actual general quantity of respondents, as all the students of this specialty took part in the survey.

\section{Theoretical background}

In the 1950s, when China was not yet such a highly developed country, the government began to look for the initial ways to increase the accessibility to broad educational opportunities. At that time, television technology was not yet available for a wide range of users, and the first television universities were set 
up in Beijing, Shanghai, and Shenyang to offer science, engineering, and liberal arts courses, which were a real breakthrough in adult education (Gao, 1991).

Currently, China is regarded as one of the most promising countries in the world, being a leading choice in cultural and educational content, as well as an affluent economy dominating the global market. The achievements of Chinese economy would have been impossible without a properly organized educational system in the country. The development of the economy inevitably entails a need for highly qualified specialists. Therefore, the Chinese government is putting in great efforts to promote economic education, investing tremendous resources in education, and currently the level of education in China meets the highest world standards.

A Chinese researcher Liu (2017) holds that the reform, which specifically concerns higher education, is an important impetus to increase the level of social development in China. However, such advances in higher education would be impossible without the digitalization of the economy, the elements of which are increasingly penetrating the citizens' everyday life. Since the beginning of China's policy of reform and openness in 1978, there has been a huge increase in the country's information and communication technologies. According to Peng (2017), with the advent of large data technology "Big Data", it's getting increasingly difficult for the teachers to arouse students' interest in learning by traditional methods and fully meet their needs for self-improvement. Furthermore, since the development of microelectronics and the advent of computers in the 1980s and the Internet in the 1990s, in the 2000s emerged robotics, artificial intelligence, blockchain technology, and in recent years there has been even a more robust growth in economy digitalization, primarily in such areas as e-commerce, financial technology, manufacturing, and education. According to a report by the Chinese Academy of Information and Communication Technologies (CAICT) under the Ministry of Industry and Information Technology of China, China's digital economy in January-June 2018 has already reached CNY 16 trillion (USD 2.32 trillion), which is equivalent to $38.2 \%$ of the country's GDP (in $2017-32.9 \%$ ) (Xinhua, 2018).

Up to date, China is not at the forefront of digitalization descriptors, but the World Bank's Digital Adaptation Index already ranks China 50th out of 131 countries, and the World Economic Forum's Digitalization Index puts China 59th out of 139 countries. This demonstrates China's strong position among innovation leaders, which is also confirmed by the government's ambitious goals of achieving a 50\% share of the digital economy in GDP by 2030 (Zhang \& Chen, 2019). Alongside with internationalizing the Belt and Road initiative, China's leader is using cross-border platforms to place a special emphasis on the growing role of digital technologies in the country's economy. Thus, the processes of digitalization and technological advances of China are associated with global trade operations, which is fundamentally important for the country's export-oriented economy. 
The development of the digital economy in China is impossible without the introduction of modern information technology (IT) in education overall and in economic education in particular. According to Chinese researchers Chen and Fan (2018), the spread of the Internet, modernization of infrastructure and enhancing the technology of the educational process promote the quality of educational programs and foster relevant knowledge, insights and new digital skills of the students. Such skills are indispensable nowadays in the digital society; they largely contribute to nurturing the students' creativity and improving their critical thinking. That is why contemporary students duly appreciate all the benefits of the Internet, which is not only a technology but also a new environment that makes it possible for them to obtain the necessary information, regardless of the location in time and space, providing the individualized learning in a networked environment beyond the traditional higher education system and other generally accepted forms of schooling (Volkova, Plotnikov \& Rukinov, 2019).

Digitalization of Chinese higher education in general and higher economic education in particular infers the implementation of a set of measures, which are developed taking into consideration the global trends in digitalization, the analysis of the state and prospects of education in modern schools, as well as the priority areas of the state project "Human Resources for Digital Economy" within the framework of the program "China's Digital Economy" (Xinhua, 2018). Let's consider the abovementioned measures in more detail.

- development and implementation of the new digital educational content, digital educational and methodological complexes (programs, materials, tools for assessing the formation of key competencies);

- gamification of the educational process, development and active implementation of educational games and digital simulators (training aids, virtual laboratories) on the basis of modern visualization technologies and augmented reality solutions. The Vietnamese and Australian researchers note that students do not sufficiently understand the benefits of the game design of the classes and are not yet accustomed to educational games as a teaching method. They believe that the gamification of learning as a process needs to be constantly adjusted to handle potential problems (Nguyen, Nguyen \& Tan, 2020). Similarly, the Chinese researchers Wang, Wang and Hu (2017) maintain the necessity to develop the game teaching methods for students. They proposed and tested a game model of curriculum design for college students and hold that such methods help to increase the level of activity, motivation and involvement of students in classroom work;

- development of distance education, expansion of the range of MOOCs (massive open online courses) conducted by the best instructors in a wide range of comprehensive subjects and areas of informal education, the importance of which is emphasized by Xiong (2018). The Chinese researcher believes that the teaching based on MOOCs can be successfully combined with traditional forms of learning;

- development of educational mobile apps, that the Ministry of Education of the People's Republic of China (2019) recommends registering in the national public register, also known as The National Digital Education Resources Public Service 
System (n. d.). Mobile applications for educational purposes must have a standardized data management system, which is to be continuously updated in the national public register and monitored by the Department of Education for feasibility, modernity, efficiency (Ministry of Education of the People's Republic of China, 2019). According to Chinese researchers Zou and Li (2015), as well as researchers Yang, Zhou and Ju (2013), mobile applications are particularly effective for learning foreign languages. Moreover, they provide for a rapid information exchange and implementation of new interaction methods between teachers and students in learning experiences;

- training of a modern teacher of the digital future, who must be able not only to efficiently use the available IT, utilize various editors, information processing tools and programs to create electronic presentations, but also to master new technologies, be particularly interested in personal growth and improvement of digital literacy and digital skills. Chinese researchers Ma, Lin and Lin (2013) believe that such training should specifically address the development of the excellent teacher's competency model, which consists of personal and professional skills.

According to the experts, such measures will enable China to set higher requirements for teacher-student interaction, to effectively implement the highprofile blended and distance learning without compromising its viability, and to motivate students toward the active engagement in the learning experiences.

\section{Results}

In June 2020, a study of the effectiveness and efficiency of distance learning of economists received 498 questionnaires of students majoring in "Business Economics" at a Chinese university. Let's analyze the empirical data obtained in the survey. The first general question involved identifying one or more online platforms that were used for distance learning. The most popular platforms for organizing and conducting distance learning for students majoring in Business Economics at Jiaxing University are provided in Table 1.

Table 1. Use of online platforms for distance learning by Business Economics students at Jiaxing University

\begin{tabular}{|c|c|c|c|}
\hline Question & Answer options & \multicolumn{2}{|c|}{ Percentage ratio } \\
\hline \multirow{3}{*}{$\begin{array}{c}\text { What online platform } \\
\text { do you use for } \\
\text { distance learning? } \\
\text { (multiple choice } \\
\text { options) }\end{array}$} & SPOC University Platform & $7.34 \%$ & 37 \\
\cline { 2 - 4 } & MOOC of Chinese universities & $73.75 \%$ & 367 \\
\cline { 2 - 4 } & Superstar Online (mobile app) & $16.3 \%$ & 81 \\
\cline { 2 - 4 } & School Online & $4.25 \%$ & 21 \\
\cline { 2 - 4 } & Wisdom Tree & $78.82 \%$ & 393 \\
\cline { 2 - 4 } & Rain Class & $35.99 \%$ & 179 \\
\cline { 2 - 4 } & Superstar Online Learning & $89.07 \%$ & 444 \\
\cline { 2 - 4 } & Platform & $35.65 \%$ & 178 \\
\cline { 2 - 4 } & WeChat & $43.9 \%$ & 219 \\
\cline { 2 - 4 } & Tencent Classroom & $38.28 \%$ & 390 \\
\cline { 2 - 4 } & QQ & $35.96 \%$ & 179 \\
\hline
\end{tabular}

The source was developed by the authors 
The respondents' answers regarding the platforms they consider the most effective for distance learning were distributed as follows (see Figure 1):

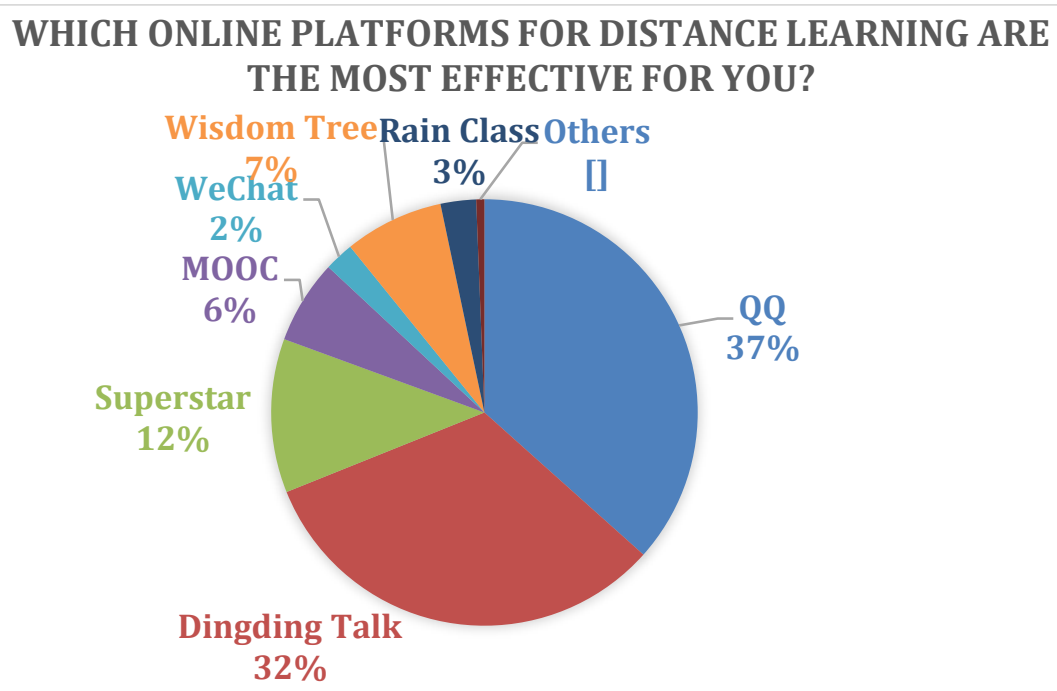

Figure 1. Effectiveness evaluation of online platforms for distance learning by the students majoring in "Business Economics" at Jiaxing University

The source was developed by the authors

The specific questions on the quality of distance learning were grouped into 3 clusters. Cluster 1 "Analysis of the online platforms and digital literacy effectiveness" contains 4 questions with 4-5 answer options. Students had to choose one option from the responses given that matched their views most closely.

High percentage of the students $(63.5 \%)$ believe that the platform chosen for use in distance learning works "perfectly" or "very well", as well as $66.3 \%$ of them rated their digital literacy in online platforms as an "expert" or an "advanced user", and $72.46 \%$ rated the teachers' digital literacy at the same level. If we were to choose among the most effective methods of teacher-student interaction, $38.54 \%$ of the students prefer the classes to be conducted in the form of online video conferencing using the presentation materials prepared by using Microsoft Power Point (PPT) software, while 34.78\% find the pre-recorded video from the screen with the help of screen-casting technology effective, which contains the teacher's video lecture accompanied by a PPT presentation in the subject under study, making use of the visual aids.

All answers to the questions of Cluster 1 and the percentage ratio of the respondents' answers are given in Table 2. 
Table 2. The data from the survey of students majoring in "Business Economics" at Jiaxing University on Cluster 1 of questions "Analysis of the online platforms and digital literacy effectiveness"

\begin{tabular}{|c|c|c|}
\hline \multicolumn{3}{|c|}{$\begin{array}{l}\text { How do you evaluate the functioning of the distance learning platform that you } \\
\text { used? }\end{array}$} \\
\hline Perfect & 49 & $9.89 \%$ \\
\hline Very good & 267 & $53.61 \%$ \\
\hline Fine & 153 & $30.79 \%$ \\
\hline $\mathrm{Bad}$ & 29 & $5.7 \%$ \\
\hline \multicolumn{3}{|c|}{$\begin{array}{l}\text { How do you evaluate your proficiency level in the distance learning platform that } \\
\text { you used? }\end{array}$} \\
\hline Expert & 61 & $12.21 \%$ \\
\hline Advanced user & 269 & $54.09 \%$ \\
\hline Confident user & 149 & $29.86 \%$ \\
\hline Novice & 19 & $3.84 \%$ \\
\hline \multicolumn{3}{|c|}{$\begin{array}{l}\text { How do you evaluate the teacher's proficiency level in the use of the distance } \\
\text { learning platform? }\end{array}$} \\
\hline Expert & 63 & $12.7 \%$ \\
\hline Advanced user & 298 & $59.76 \%$ \\
\hline Confident user & 128 & $25.68 \%$ \\
\hline Novice & 9 & $1.86 \%$ \\
\hline \multicolumn{3}{|c|}{$\begin{array}{l}\text { In your opinion, which method of interaction with the teacher during a distance } \\
\text { lesson works best? }\end{array}$} \\
\hline $\begin{array}{l}\text { Pre-loaded PPT + audio recording } \\
\text { of the lesson }\end{array}$ & 46 & $9.17 \%$ \\
\hline $\begin{array}{l}\text { Pre-loaded PPT + video recording } \\
\text { of the lesson }\end{array}$ & 173 & $34.78 \%$ \\
\hline PPT + online audio conferencing & 75 & $15.14 \%$ \\
\hline PPT + online video conferencing & 192 & $38.54 \%$ \\
\hline Other & 12 & $2.37 \%$ \\
\hline
\end{tabular}

The source was developed by the authors

Cluster 2 "Analysis of the distance learning content" contains 5 questions with 4-5 possible options. Students had to choose one option from the responses given, which matched their views most closely.

Most of the students (95.33\%) students said that they review and study the materials provided by the teacher on the online platform before distance learning. Large percentage of the students $(82.03 \%)$ fully or very well understand the objectives of the disciplines, assignments, homework requirements, assessment types used during distance learning, and $76.79 \%$ have a "very convenient" or a "convenient" access to online materials on the platforms in accordance with the learning objectives. More than half of the students $(57.16 \%)$ believe that in the format of distance learning it is possible to efficiently cope with the difficulties and master the complexities of each subject, while $65.12 \%$ noted that the tasks provided by the teacher in the online format had been fairly useful and interesting, and could enhance their interest in learning. 
All answers to the questions of Cluster 2 and the percentage ratio of the respondents' answers are given in Table 3.

Table 3. The data from the survey of students majoring in "Business Economics" at Jiaxing University on Cluster 2 of questions "Analysis of the distance learning content"

Do you review the materials provided by the teacher on the online platform before the distance lesson?

\begin{tabular}{|c|c|c|}
\hline Almost always & 81 & $16.33 \%$ \\
\hline Very often & 164 & $32.87 \%$ \\
\hline Occasionally & 230 & $46.13 \%$ \\
\hline Never & 14 & $2.89 \%$ \\
\hline Hard to answer & 9 & $1.78 \%$ \\
\hline
\end{tabular}

Do you fully understand the objectives of studying the disciplines, assignments, homework requirements, assessment types?

\begin{tabular}{|c|c|c|}
\hline I fully understand & 88 & $17.65 \%$ \\
\hline I understand very well & 320 & $64.38 \%$ \\
\hline I partly understand & 82 & $16.39 \%$ \\
\hline I do not understand enough & 8 & $1.57 \%$ \\
\hline \multicolumn{3}{|c|}{$\begin{array}{c}\text { Is it convenient for you to access the online materials in accordance with you } \\
\text { learning objectives? }\end{array}$} \\
\hline Very convenient & 103 & $20.79 \%$ \\
\hline Convenient & 279 & $56 \%$ \\
\hline Fairly convenient & 94 & $18.86 \%$ \\
\hline Not very convenient & 22 & $4.35 \%$ \\
\hline
\end{tabular}

Can you effectively cope with the difficulties and master the complexities of each of the disciplines in the distance learning format?

\begin{tabular}{|c|c|c|}
\hline I always can & 54 & $10.74 \%$ \\
\hline I almost always can & 231 & $46.42 \%$ \\
\hline I often can & 182 & $36.56 \%$ \\
\hline I can't always & 31 & $6.28 \%$ \\
\hline
\end{tabular}

Do you think that the tasks provided by the teacher are useful and interesting? Can they stimulate your interest in learning?

\begin{tabular}{|c|c|c|}
\hline Always & 67 & $13.47 \%$ \\
\hline Almost always & 257 & $51.65 \%$ \\
\hline Often & 155 & $31.02 \%$ \\
\hline Not enough & 19 & $3.86 \%$ \\
\hline
\end{tabular}

The source was developed by the authors

Cluster 3 "Effectiveness and efficiency of distance learning" contains 5 questions with 2-4 answer options, from which students had to choose the one that most closely matched their views.

More than half of the students $(69.19 \%)$ consider the delivery of the online courses in distance learning format to be "very effective" or "effective", 63.03\% of them noted a variety of interactive forms, methods and technologies of distance learning, and $68.18 \%$ believe that the various methods of online knowledge control (surveys, essays, online tests) used by the teachers help them better master the content of academic disciplines in format of distance learning. 
Almost all the students (91.37\%) noted that their teachers were "always insightful" or "almost always insightful" about organizing online discussions, explaining answers to difficult questions, assessing homework.

Despite the fact that students highly assessed the quality of delivering and conducting the distance learning, at the end of the survey in response to the last question about whether the students would choose distance or classroom learning in view of the atmosphere, activation of learning, effectiveness of lecture material, interactive forms, learning efficiency, $72.33 \%$ of the students still preferred classroom forms of learning.

All answers to Cluster 3 of questions and the percentage of respondents' answers are given in Table 4.

Table 4. The data from the survey of students majoring in "Business Economics" at Jiaxing University on Cluster 3 of questions "Effectiveness and impact of distance learning"

Do you consider the organization of online courses in distance learning format to be effective?

\begin{tabular}{|c|c|c|}
\hline Very effective organization & 65 & $12.96 \%$ \\
\hline Effective organization & 280 & $56.23 \%$ \\
\hline Well organized & 130 & $26.12 \%$ \\
\hline Organized not well enough & 23 & $4.69 \%$ \\
\hline
\end{tabular}

Do you think that the tasks of online courses involve a variety of interactive forms and technologies which is wide enough?

\begin{tabular}{|c|c|c|}
\hline Always & 82 & $16.46 \%$ \\
\hline Almost always & 227 & $45.57 \%$ \\
\hline Often & 166 & $33.43 \%$ \\
\hline Not enough & 23 & $4.54 \%$ \\
\hline
\end{tabular}

Do different methods of online knowledge control (surveys, essays, online tests) help you to better master the content of academic disciplines in the format of distance learning?

\begin{tabular}{|c|c|c|}
\hline Always & 340 & $68.18 \%$ \\
\hline Almost always & 143 & $28.72 \%$ \\
\hline Often & 15 & $3.11 \%$ \\
\hline
\end{tabular}

Is your teacher insightful enough about organizing online discussions, explaining answers to difficult questions, and assessing homework?

\begin{tabular}{|c|c|c|}
\hline Always insightful & 252 & $50.7 \%$ \\
\hline Almost always insightful & 203 & $40.67 \%$ \\
\hline Insightful enough & 39 & $7.81 \%$ \\
\hline Not insightful enough & 4 & $0.82 \%$ \\
\hline \multicolumn{3}{|c|}{$\begin{array}{l}\text { Do you prefer distance or classroom learning (given the atmosphere, intensification } \\
\text { of learning, the effectiveness of learning material, interactive forms, learning impact) }\end{array}$} \\
\hline Distance learning & 138 & $27.77 \%$ \\
\hline Classroom training & 360 & $72.33 \%$ \\
\hline
\end{tabular}

The source was developed by the authors 


\section{Discussion}

Modern university teachers around the world have been adapting themselves to distance learning in force majeure circumstances caused by the COVID-19 pandemic. In particular, they had to organize communication with students, ensure their active participation during distance learning, prepare learning content, monitor and evaluate the results of training, provide correction. Teachers of Chinese universities were the first ones to face a new format of education. The experience of training students majoring in Business Economics in China in force majeure circumstances indicates high level of the educational process organization. At the same time, high-quality technological support does not guarantee a comprehensive solution to all tasks related to distance learning.

Training of specialists in Business Economics in quarantine conditions provided for the selection of such platforms for classes that would ensure the implementation of cognitive, practical and motivational learning goals. During the survey, the students of Business Economics at the Chinese university noted that the platforms / apps for distance learning that they most often use are Superstar Online Learning Platform, Wisdom Tree, QQ (Tencent Conference, Tencent Classroom), MOOC platforms of Chinese universities, as well as Dingding Talk. Let us consider that all these platforms have a wide range of functions to conduct distance learning classes: a chat for communication between teachers and students, a possibility of group audio and video conferences, a screen-casting function (Washburn, 2009), which is given special relevance in modern distance education, as well as a separate unit for downloading homework in the format of audio, voice messages, photos, text files, presentations, etc. WeChat, which has also been singled out as one of the apps often used by both students and teachers of Chinese higher education institutions, is also a platform that has not lost its relevance for many years due to the wide range of educational content for distance learning by creating group chats between teachers and students, thus making the information exchange more efficient (Tu, Yan, Jie, Ying \& Huang, 2018).

As a result of the analysis of the teachers' experience in conducting distance learning disciplines and applying the benefits of the Internet development in China (Tsytsiura \& Gao, 2020), it was shown that students' attendance on the Internet was monitored on a daily basis, and the level of attendance was high as a rule. Teachers' choices of online platforms / tools for distance learning are mainly focused on QQ (Tencent Classroom), DingDing Talk, Superstar Online, open MOOC courses from Chinese universities and Wisdom Tree. Many teachers also chose the ZOOM platform for distance learning, making note of a good feedback effect. Apart from the fact that each teacher had the opportunity to choose alternative platforms and methods of interaction with students, most still chose the method of "PPT + online audio conferencing" or "PPT + online video conferencing". So, while preparing for the lesson, each teacher preuploaded the lesson materials on to the teaching platform or to the self-created groups in messengers. 
We emphasize that the degree of compliance of educational resources from online platforms with the content of the courses on the educational and professional program "Business Economics" (Jiaxing University, 2018) is high; prior to distance learning on the Internet, teachers chiefly informed students about the content of the discipline, its objectives, requirements for learning and homework, etc. In the course of online instruction, the teachers followed a set plan for the most part. The interactive forms of online teaching used in the distance learning process are quite diverse, and teachers are usually quite knowledgeable in the online platform operation. The structure of the courses, the general outline of the educational activity is organized fairly well, and all students have completed the tasks of academic disciplines according to the schedule by the end of the semester.

According to the survey statistics, students generally have a positive experience of online learning, which was introduced by the university in a special epidemiological period, but most students feel the need for classroom learning. A similar position is observed among students of universities in Eastern and Central Europe, who do not agree with the statement that distance learning could replace face-to-face learning (Vasilevska, Rivza, Alekneviciene \& Parlińska, 2017).

So, Chinese universities have been constantly exploring the ways to enhance the quality of online teaching, trying to achieve the same quality, efficiency and effectiveness from online teaching as from traditional or blended forms. This is emphasized by Chinese researcher $\mathrm{Li}$ (2019), who believes that traditional methods are becoming increasingly difficult to adapt to a changing society, and the web-based teaching and visualization are especially effective for students of the XXI information century.

The results obtained during the study confirm the hypothesis about the effectiveness of distance business education in force majeure circumstances in China and the feasibility of introducing the Chinese innovative elements of distance learning into Eastern European economic education.

Based on the results of the experiment and research conducted, the recommendations were formulated to increase the efficiency and effectiveness of online learning in Eastern European countries.

\section{(1) Enhancing the monitoring of the teaching quality}

To enhance the monitoring of the teaching quality it is advised to systematically improve the quality of distance learning, the college and university management should fully highlight the quality of the teaching process, learning and interaction between the participants of the educational process in distance form; improve the timeliness of feedback from both the teachers and students for a timely correction of errors and problem solving. It is also advised to continuously promote the teachers' digital competence, which will provide for a high level of distance economic education. It is vital to improve the accuracy and depth of the teachers' feedback information analysis, to use the data of such analysis for a timely discussion and solution of distance education problems, if 
any, in the respective departments of relevant institutes and to promote good practices. The adoption of these measures will ensure the objective recognition of the development status and competitiveness of higher education, which is an important prerequisite and rationale for its transformation (Wen, Yin \& Xu, 2018).

\section{(2) Continuous enhancement of learning performance for students}

It is advised to proceed with studying the students' online learning experiences, taking into account their needs and learning performance indicators. An important step in this direction is the exploration of the styles of social media and smartphones use in higher education (Gumeta \& Khan, 2017). It is essential to encourage the teachers to choose QQ (Tencent Meeting, Tencent Classroom), DingDing Talk and other experimentally tested platforms, as well as the interaction methods "PPT + online video conferencing" and "Pre-loaded PPT + video recording of the lesson", which, according to the students' opinion, increase the efficiency of their learning material; strengthen the interaction between teachers and students in the learning process, enrich the variety of interactive forms and means of enhancing the efficiency and effectiveness of distance learning. A particularly important component of this process is the study of the teachers' acceptance and intentions of using Web-technologies in distance learning in current educational context and perception of the realities for the teachers to make use of these technologies for pedagogical purposes ( $\mathrm{Li}$ \& Kim, 2018; Teo, Guoyuan, Mei \& Hoi, 2018). It is important to encourage the teachers to motivate their students for independent education, promoting initiatives, boosting personal growth, shaping a positive attitude to distance learning and self-demand while studying in force majeure circumstances. Chinese researchers agree that one of the best motivating components of learning for economics students is the use of problem-based learning, which also improves their communicative competence and active independent learning skills, which are very important prerequisites for future economists (Lin, 2017; Liu, 2016).

\section{(3) Effective improvement of the online teaching level and the online education content}

It is advisable to identify the best online courses and programs in order to organize networking activities, to identify difficulties and ways to handle them. Encouraging teachers to timely adjust the online training content, the teaching methods and interaction with students based on students' feedback and suggestions is necessary. It is also important to strengthen the links between universities by organizing video conferences, discussions of effective forms and methods of distance learning aimed at promoting an effective performance on the Internet.

\section{Conclusions}

Thus, distance learning in force majeure circumstances should ensure the effectiveness of professional training, have appropriate methodological support, and meet the requirements for accessibility, interactivity, and high-quality feedback. Analysis of the good practices in distance learning during the training of economists in China allowed identifying the following factors of its 
effectiveness: the quality information and educational environment, the openness of the college and university management and faculty to change, the corporate training of the educators, the motivation of students and formation of their digital competence, a comprehensive support of distance learning. Important features of the educational process in force majeure circumstances are variability and flexibility, when each teacher has the opportunity to choose the alternative platforms and methods of interaction with students. The most effective distance learning platforms highlighted by the students who took part in the survey are the ones that are multifunctional, provide ample opportunities for the use of interactive learning technologies, have the capabilities of the "flipped classroom", provide high-quality feedback. The quality assurance of distance learning content involves the development and implementation of a new digital educational content, digital educational and methodological complex (programs, materials, tools for evaluating the formation of key competencies). Both teachers and students need special training in the use of distance technology, which was provided at Jiaxing University through corporate teacher training based on online conferences, webinars, online student counseling. The results of the survey indicate that the majority of respondents evaluate the level of mastering the platform by both students and teachers as sufficient (an "advanced user").

The results show that distance learning has certain organizational advantages over the classroom instruction: all procedures related to the presence, timeliness of tasks are formalized, control methods are diversified, opportunities for flipped learning are fully provided, when students are exposed to the theoretical material in advance, and in the course of online classes it is consolidated in an interactive learning environment. Regarding the presentation of educational information, it is important to note that in terms of the quantity of answers, given in the survey, the majority of the respondents are those who prefer online conferences, the second place is given to pre-recorded video lectures, and the third - to audio-conferences. This gives us grounds to conclude that live communication is important for the students, however they highly appreciate the visualization of information as well. A significant number of students admit that they review the materials provided by the teacher on the online platform before online classes, which allows us to state the lack of readiness of students for flipped learning, when classes are mostly practice-oriented rather than theoretical. At the same time, the fact that distance learning has its limitations cannot be underestimated. In particular, most students highlighted the need for face-to-face learning in the context of dynamic interaction effectiveness between teacher and students, as well as students among themselves in the classroom. In force majeure circumstances, this need was to some extent underwritten by a synchronous communication during online video conferencing classes with the use of presentation materials. Availability of the pre-recorded video from the screen with the help of screen-casting technology improves the students' knowledge assimilation capacity but cannot replace the face-to-face communication. 


\section{References}

Chen, Q., \& Fan, Y. (2018). Research on the impact of internet development on the quality of China's higher education. Educational Sciences: Theory \& Practice, 18(5), 1531-1539. http://dx.doi.org/10.12738/estp.2018.5.050

European Commission. (2010a). A digital agenda for Europe [e-book]. Retrieved from https://eur-

lex.europa.eu/LexUriServ/LexUriServ.do?uri=COM:2010:0245:FIN:EN:PDF

European Commission. (2010b). A strategy for smart, sustainable and inclusive growth [ebook]. $\quad$ Retrieved from https://eurlex.europa.eu/LexUriServ/LexUriServ.do?uri=COM:2010:2020:FIN:EN:PDF

Gao, F. (1991). The challenge of distance education in China. American Journal of Distance Education, 5(2), 54-58. https://doi.org/10.1080/08923649109526750

Gumeta, H., \& Khan, J. (2017). Where is mobile learning going in China? In L. Gómez Chova, A. López Martínez, \& I. Candel Torres (Eds.), 11th International Technology, Education and Development Conference (pp. 2750-2759). Valencia, Spain. Retrieved from https://doi.org/10.21125/inted.2017.0751

Jiaxing University. (2018). Educational and professional program for Bachelor's Degree. Jiaxing, China: Jiaxing University Academic Office Publishers.

Jiaxing University. (n.d.). Retrieved from http://www.zjxu.edu.cn

Khan, B. H., \& Ally, M. (Eds.). (2015). International handbook of E-learning. Theoretical perspectives and research (Vol. 1). London, UK: Routledge.

Li, G.-L., \& Kim, H.-T. (2018). The challenge and response of Chinese university teachers in the era of "Internet + ". Chinese Studies, 64, 85-98. http:/ / dx.doi.org/10.14378/KACS.2018.64.64.5

Li, R. (2019). Effect of synchronous web-based teaching combined with visually creative teaching under the background of information science. The Electronic Library, 37(5), 830-841. https://doi.org/10.1108/EL-02-2019-0023

Lin, L.-F. (2017). Impacts of the problem-based learning pedagogy on English learners' reading comprehension, strategy use, and active learning attitudes. Journal of

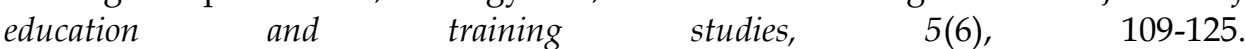
https://doi.org/10.11114/jets.v5i6.2320

Liu, M. (2017). Research on college English teaching reform under "Internet + applied talent" training mode. Agro Food Industry Hi-Tech, 28(3), 3363-3365.

Liu, X. (2016). Motivation management of project-based learning for business English adult learners. International Journal of Higher Education, 5(3), 137-145. https:// doi.org/10.5430/ijhe.v5n3p137

Ma, W., Lin, F., \& Lin, J. (2013, December). Research on Chinese University teacher's competency. Proceedings of the 2013 International Conference on Advances in Social Science, Humanities, and Management (pp. 821-826). Amsterdam, Netherlands: Atlantis Press. https://doi.org/10.2991/asshm-13.2013.153

Ministry of Education of the People's Republic of China. (2019, November 11). The administrative measures for record-filing mobile Internet applications for education. Retrieved from http://www.moe.gov.cn/srcsite/A16/s3342/201911/t20191122_409333.html

Nguyen, L. T. M., Nguyen, L. T. M., \& Tan, G. (2020). Gamification in business education: An experience sharing. Proceedings of the 2020 2nd International Conference on Modern Educational Technology: ICMET '20 (pp. 34-39). New York, NY: Association for Computing Machinery. https://doi.org/10.1145/3401861.3401867 
Peng, B. (2017). Construction and application of the BEST teaching mode of college English in big data. International Journal of Emerging Technologies in Learning, 12(9), 41-50.

Teo, T., Guoyuan, S., Mei, B., \& Hoi, C. (2018). Investigating pre-service teachers' acceptance of Web 2.0 technologies in their future teaching: A Chinese perspective. Interactive Learning Environments. 27(4), 530-546. https://doi.org/10.1080/10494820.2018.1489290

The National Digital Education Resources Public Service System. (n.d.). Retrieved from http://app.eduyun.cn/

Tsytsiura, K., \& Wanquan, G. (2020). Internet Plus strategy as a factor of development of economic education in the People's Republic of China. Scientific Journal of Polonia University, 38(1-2), 291-300. https://doi.org/10.23856/3879

Tu, S., Yan, X., Jie, K., Ying, M., \& Huang, C. (2018). WeChat: An applicable and flexible social app software for mobile teaching. Biochemistry and Molecular Biology Education, 46(5), 555-560. https://doi.org/10.1002/bmb.21170

Vasilevska, D., Rivza, B., Alekneviciene, V., \& Parlińska, A. (2017). Analysis of the demand for distance education at Eastern and Central European higher education institutions. Journal of Teacher Education for Sustainability, 19(1), 106116. https://doi.org/10.1515/jtes-2017-0007

Volkova, A. A., Plotnikov, V. A., \& Rukinov, M. V. (2019). Digital economy: Essence of the phenomenon, problem and risks of formation and development. Administrative Consulting, 4, 38-49. https://doi.org/10.22394/1726-1139-2019-4$38-49$

Wang, F., Wang, Y., \& Hu, X. (2017). Gamification teaching reform for higher vocational education in China: A case study on layout and management of distribution center. International Journal of Emerging Technologies in Learning, 12(9), 130-144.

Washburn, A. (2009). Screen casting library tutorials for distance learners: A user evaluation. Indiana Libraries, 28 (3), 49-57.

Wen, X., Yin, Y., \& Xu, J. (2018). Evaluation and Analysis of competitiveness of regional higher education in China based on individual advantage characteristic. Educational Sciences: Theory $\mathcal{E}$ Practice, 18(5), 1459-1472. http://dx.doi.org/10.12738/estp.2018.5.043

Xinhua. (2018, December 23). Report: China's digital economy contributes more to GDP. China Daily. Retrieved from https://www.chinadailyhk.com/articles/132/187/31/1545558119154.html

Xiong, Q. L. (2018). College English MOOC teaching on SWOT analysis. Educational Sciences: Theory \& Practice, 18(6), 3529-3535. http://dx.doi.org/10.12738/estp.2018.6.263

Yang, B., Zhou, Sh., \& Ju, W. (2013). Learning English speaking through mobile-based role-plays: The exploration of a mobile English language learning app called engage. The EuroCALL Review, 21(2), 27-38. https://doi.org/10.4995/eurocall.2013.9788

Zhang, L., \& Chen, S. (2019). China's Digital Economy: Opportunities and Risks: IMF Working Paper No. 19/16. Washington, D.C., United States: International Monetary Fund.

Zou, B., \& Li, J. (2015, December 2). Exploring mobile apps for English language teaching and learning. In F. Helm, L. Bradley, M. Guarda, \& S. Thouësny (Eds.), Critical CALL - Proceedings of the 2015 EUROCALL Conference (pp. 564-568). Padova, Italy: Research-publishing.net. http://dx.doi.org/10.14705/rpnet.2015.000394 


\section{Appendix A}

Questionnaire for evaluating the effectiveness and efficiency of distance learning in force majeure by students majoring in "Business Economics" at Jiaxing University

\begin{tabular}{|c|c|}
\hline Question & Answer options \\
\hline \multirow{11}{*}{$\begin{array}{l}\text { What online platform do you use } \\
\text { for distance learning? (choose } \\
\text { multiple choice options) }\end{array}$} & SPOC University Platform \\
\hline & MOOC of Chinese universities \\
\hline & Superstar Online APP \\
\hline & School Online \\
\hline & Wisdom Tree \\
\hline & Rain Class \\
\hline & Superstar Online Learning Platform \\
\hline & WeChat \\
\hline & Tencent Classroom \\
\hline & $\mathrm{QQ}$ \\
\hline & Other \\
\hline
\end{tabular}

CLUSTER 1. Analysis of the online platforms and digital literacy effectiveness

\begin{tabular}{|c|}
\hline $\begin{array}{c}\text { How do you evaluate the functioning of the distance learning platform that you } \\
\text { used? }\end{array}$ \\
\hline Perfect \\
\hline Very good \\
\hline Fine \\
\hline Bad \\
\hline How do you evaluate your proficiency level in the distance learning platform that \\
you used? \\
\hline Expert \\
\hline Advanced user \\
\hline Confident user \\
\hline Novice \\
\hline How do you evaluate the teacher's proficiency level in the use of the distance \\
learning platform? \\
\hline Expert \\
\hline Advanced user \\
\hline Confident user \\
\hline Novice \\
\hline In your opinion, which method of interaction with the teacher during a distance \\
lesson works best? \\
\hline Pre-loaded PPT + audio recording of the lesson \\
\hline Pre-loaded PPT + video recording of the lesson \\
\hline PPT + online audio conferencing \\
\hline PPT + online video conferencing \\
\hline Other \\
\hline
\end{tabular}




\section{CLUSTER 2. Analysis of the distance learning content}

\begin{tabular}{|c|}
\hline $\begin{array}{c}\text { Do you review the materials provided by the teacher on the online platform before } \\
\text { the distance lesson? }\end{array}$ \\
\hline Almost always \\
\hline Very often \\
\hline Occasionally \\
Never \\
\hline Hard to answer \\
\hline Do you fully understand the objectives of studying the disciplines, assignments, \\
homework requirements, assessment types? \\
\hline I fully understand \\
\hline I understand well \\
\hline I partly understand \\
\hline I do not understand enough \\
\hline learning objectives? \\
\hline Very convenient \\
\hline Fairly convenient \\
Convenient \\
\hline Not very convenient \\
\hline it convenient for you to access the online materials in accordance with your \\
\hline Can you effectively cope with the difficulties and master the complexities of each of \\
the disciplines in the distance learning format? \\
\hline I always can \\
\hline I almost always can \\
\hline I often can \\
\hline I can't always \\
\hline Do you think that the tasks provided by the teacher are useful and interesting? Can \\
they stimulate your interest in learning? \\
\hline Always \\
\hline Almost always \\
\hline Often \\
\hline Not enough \\
\hline
\end{tabular}

\section{CLUSTER 3. Effectiveness and impact of distance learning}

Do you consider the organization of online courses in distance learning format to be effective?

Very effective organization
Effective organization
Well organized
Organized not well enough

Do you think that the tasks of online courses involve a variety of interactive forms and technologies which is wide enough?

Always

Almost always

Often

Not enough

Do different methods of online knowledge control (surveys, essays, online tests) help you to better master the content of academic disciplines in the format of distance learning? 


\begin{tabular}{|c|}
\hline Always \\
\hline Almost always \\
\hline Often \\
\hline $\begin{array}{c}\text { Is your teacher insightful enough about organizing online discussions, explaining } \\
\text { answers to difficult questions, and assessing homework? }\end{array}$ \\
\hline Always insightful \\
\hline Almost always insightful \\
\hline Insightful enough \\
\hline Not insightful enough \\
\hline $\begin{array}{c}\text { Do you prefer distance or classroom learning (given the atmosphere, intensification } \\
\text { of learning, the effectiveness of learning material, interactive forms, learning impact) }\end{array}$ \\
\hline Distance learning \\
\hline Classroom training \\
\hline
\end{tabular}

